\title{
Youth and the Marathon
}

\section{William J. Cromie}

To cite this article: William J. Cromie (1909) Youth and the Marathon, The Pedagogical Seminary, 16:3, 331-336, DOI: 10.1080/08919402.1909.10532587

To link to this article: http://dx.doi.org/10.1080/08919402.1909.10532587

曲 Published online: 30 Aug 2012.

Submit your article to this journal 2

III Article views: 6

Q View related articles $\sqsubset$ 


\section{YOUTH AND THE MARATHON ${ }^{1}$}

By William J. Cromie

Instructor in Gymnastics, University of Pennsylvania

Long distance running has been in vogue almost since the beginning of bistory, and, throughout the centuries to the present time, has been more or less overdone and abused owing to the fact that some indulged who were not physically fit, or who had neither sufficient nor proper preliminary physical training.

It is said that, centuries before the Christian era, Ladas, a Spartan, after running in the Greek Stadium a distance of only a little more than three miles, won his race and dropped dead after crossing the goal. This man must have been in poor physical condition, or else was not properly trained. Again, in the Stadium, the men did not run on firm earth, but in soft sand, and this made ranning fast doubly difficult.

Many long runs besides the Marathon have been accomplished by men in the past. Before the Battle of Marathon, when the Persian attack was imminent, the Athenians sent Phidippides to Sparta to summon help. The distance was one hundred and fifty miles; this he covered in forty-eight hours. On February twenty-second, i882, J. Saunders, of New York, ran one hundred miles in seventeen hours thirty-six minutes and fourteen seconds. J. E. Dixon, of Balham, England, ran fifty miles in six hours eighteen minutes twenty-six and onefifth seconds, on April eleventh, 1885. Both of these men were amateur runners. Charles Rowell, a professional runner, on February twenty-seventh, I882, ran one hundred miles in thirteen hours twenty-six minutes and thirty seconds, and, on October twenty-fourth, I882, ran two hundred miles in thirty-five hours nine minutes twenty-eight seconds. According to these figures we find that the one bundred and fifty mile run of Phidippides in forty-eight hours was not such a great atbletic event.

\section{The Marathon}

The present Marathon race, which consists of twenty-six miles three hundred and eighty-five yards, is the most strenuous and arduous of all our modern sports. It is very difficult

${ }^{1}$ An Address before the Conference on Child Welfare at Clark University, Worcester, July, rgog. 
to select the man or youth who can withstand the strain of repeated endurance runs of twenty-five miles without injury. Many claim that the Marathon does no harm; that if one can run five miles he can run ten; and, if be can run ten, he can run twenty and even twenty-five miles. Some of these supporters tell us to "take a look" at the ancient Greeks and observe their superb development, their physical perfection; their great strength, skill and endurance. We look backward and read that Xenophon, the Athenian historian, who lived 435 to 354 B. C., complained that the Greeks specialized too much, and that by so doing developed a race of ill-proportioned athletes. He said that the runners' limbs were wonderful, but that their shoulders were poor. This historian also asserted that the Greek figures that we admire so much in our art galleries were not types, but were the composite of several figures.

Plato, the Greek philosopher, described some of the athletes of his time as "sleeping away their lives"; while Galen, the Greek physician, in speaking of the Greek and Roman athletes said that some of them were "heavy and stupid." The Greeks were not superior to the athletes of to-day; in fact, the Americans are the greatest athletes in the world, but even they are in danger of overtraining. Some of the feats of the Greeks are very vague and indefinite, as some of the short distance races were measured by "the distance a youth could throw a stove;" others were of a distance that "an ox could draw a plough during the hours of daylight." Such measurements leave us in doubt as to what the distances were.

\section{Revival, of tha Marathon}

In 1896 the first of the modern Olympiads was held in Athens, Greece. The principal event was a foot race from the battlefield of Marathon to the goal of the Stadium, a distance of 26. I miles. The popularity of this race was due to the fact that in 490 B.C. on the plain of Marathon, the Athenians and Platoans under Miltiades defeated the Persians. A messenger of Miltiades ran from the battlefield of Marathon to Athens, and retained sufficient breath to cry out the defeat of the Persians; halted in his tracks-and dropped dead. The first three men to finish in the modern Marathon race, over the same course that it is supposed the messenger of Miltiades ran, were Greeks. Louis, who finished first, and his two Greek companions, were greeted with a cheer that has re-echoed around the world, and made Marathon running our most popular sport. At that time Louis was acclaimed a hero by all nations, for was it not Greece that inaugurated that classic event when she was the ruling nation of the world? 
It seemed then a settled fact that in Greece the world's greatest long distance runners were bred and developed. But Greece did not long hold the supremacy, for many stars now shine brilliantly in the universe of long distance running. John J. Hayes, the American, holds the championship Marathon trophy by virtue of his winning it at the Olympic games held in London July, 1908. It is largely due to this fact that the run bas become so popular in America. John Hayes has been practicing long distance running for years, and is a veteran at this kind of sport.

Then there is Alfred Schrubb, the English physical marvel. $\mathrm{He}$ has also had many years of training. The English have been exponents of distance running for over fifty years. The successful Marathon runner is he who has a strong physique and who has had much preparation. Tom Longboat, the fleet Indian, has been in training for years. Dorando Pietri, the Italian, has been running since he was a messenger boy in Capri, Italy, and had he not been interfered with by overzealous officials, might have won the great Marathon.

These are the pioneers - the men who have blazed the forests of long distance running. Many lesser lights are following closely in their pathway - but have they the physique, the necessary long, arduous training that is essential to an endurance test of this nature?

\section{EFFECTS OF OVER-RUNNING}

Doctor R. Tait Mackenzie, Professor of Physical Education in the University of Pennsylvania, and a noted sculptor, has made four masks that cover the conditions experienced by runners; they are called effort, breathlessness, fatigue, and exhaustion.

\section{EFPORT}

"Effort," said Fernard Lagrange, M. D., "is a physiological action which consists in the association of great numbers of muscles and bones, that they may assist in the same movement, and which, moreover, brings into active association with the muscular work two great functions of the economy-respiration and circulation." The effort that is required in long-distance running is a phenomenon that is intimately connected with very great expenditure of force, and if indulged in long enough will finally result in the suspension of the respiratory movement. Even localized effort will bring about this result. For instance, a man can crack a nut with a thin shell between the fingers, and the muscular action will be confined to the fingers and forearm; but, if the shell is thick and the man has to use all his force, the muscular contraction extends to the arm, the 
shoulder, and finally to the neck, chest and abdomen. Respiration stops, the face becomes flushed and congested, and the veins of the forehead and neck fill and become prominent.

This man's condition at the moment is similar to that of the man who is running, and whose facial expression denotes violent effort. The runner does not hold his breath in the same manner as the "nut cracker," but the physiological action is the same, viz., that a disturbance is occurring in the system which momentarily hinders respiration and circulation. The blood pressure in the veins and arteries is increased, and the breathing is quickened. Violent effort, as seen in Doctor Mackenzie's clay model, produces remarkable changes in the facial expression. The nostrils are dilated, the lips are retracted, the eyes squint, and the general expression of the face is repulsive.

\section{BREATHLESSNESS}

If violent effort be persisted in for some time, the runner becomes breathless. The rhythm of respiration becomes irregular. The inspiration becomes much more prolonged than expiration; the breathing is almost a gasp. At this stage the runner somewhat resembles an intoxicated person. "In breathlessness," says Doctor Mackenzie, "the upper lids droop and half cover the eye, giving a look of great lassitude to the suffering expressed by this region of the face. The nostrils are widely dilated, the mouth gapes, and the lips are retracted in the mad struggle for air. The general pose of the head is backward, and the chin is thrust forward."

\section{FATIGUe}

In fatigue, the entire system is affected. There is a pounding in the temples; sparks and flashes of light appear before the eyes; ringing noises are heard, and the chest feels as if it were oppressed by a weight, and the air inhaled has a "burning" sensation. When one becomes fatigued under the influence of enforced running, the face takes on a leaden hue. In no case should one be permitted to continue running when this condition presents itself, as it means the beginning of asphyxia.

\section{ExHAUSTION}

Often when a runner is almost exhausted, when the head feels as if bound by an iron band; when he is almost unconscious of passing events, he will still force the tired legs forward until they refuse to act, and he falls to the ground exhausted or in a faint. When one is in this condition, his respiration is short, jerky and occasionally interrupted. The 
heart beat is feeble and intermittent, while the pulse is irregu. lar and almost imperceptible. When running is continued to these extreme limits, grave dangers may be encountered. Some horses will run until they drop dead from exhaustion if the whip is applied. The same holds true of men and boys if the whip of violent effort is applied to the extreme. The case of the first Marathon runner furnishes us with a striking example of the terrible penalty of excess in running.

\section{Schoor, Boys}

All physical trainers should sound a note of warning against boys entering long endurance runs. Immature boys and young men who work or study all day should be discouraged against training for the Marathon at night or on Sundays, as it necessarily takes a great deal of time which in their case should be spent in sleep or rest. A boy cannot afford to run three or four hours after supper, as the strain is too great. It is rather serious for a trainer or director to have young men return to him in a few years with nervous breakdown or chronic beart and lung affections due to strain or overtraining, and blame the coach for their loss of health.

Newspapers in many cities are conducting Marathon runs, and offering valuable prizes for the successful contestants. This, together with publicity, tempts many who are not physically fit to enter these races. On February roth a Pittsburg newspaper conducted a run of ten wiles in which there were 4,900 entries. It is claimed that none of the contestants were over sixteen years of age. Can it be possible that all of these lads were in the proper physical condition to run even ten miles?

Some of these newspapers have the contestants run the full Marathon course. Recently, in New Castle, $\mathrm{Pa}$., one of the prominent newspapers conducted such a run, and a youth fourteen years of age, who finished ninth in the race, was acclaimed a hero. There were over eighty entered in this race, some of whom were men. Surely, a boy cannot compete with strong men and trained college students. In some cases, seasoned Marathon runners act as coaches in connection with these runs. These men are apt to overrate the powers of beginners and "push them too hard."

Michael Murphy, the noted athleic trainer who coached the American team for the Olympic Games held in London July, 1908, in speaking of distance running recently said: "The colleges have found that seven and three-quarter miles is about the best distance for their cross country championships, and the collegians are good runners. On a flat track they could safely go further-perhaps the Marathon distance without any 
bad results. Distance running, when the competitor is properly trained, is one of the finest of sports, but the youngsters should be kept away from the game."

Recently, a group of eminent English physicians stamped their disapproval on Marathon races among boys. Such famous physicians as Sir Lauder Brunton, Sir Thomas Barlow and Sir Alfred Tripp signed the following strongly worded statement, which was sent to every British school: "We have no hesitation in saying that we consider that school and cross country races exceeding one mile in distance are wholly unsuitable for boys under the age of nineteen, as the continued strain involved is apt to cause permanent injury to the heart and other organs."

Usually, the Americans are extremists in sports as in everything else. What we need more is a system of improving all muscles and making them co-ordinate to the mind. Boys should practice for skill and agility; also to gain calm, steady nerve. They should take part in events which are moderate, and which give physical poise and efficiency. A Marathon relay race with twenty-six boys, or even fifty-two boys entered, would be far superior to one boy straining to run the full Marathon course. Running, or, in fact, any form of gymnastics or athletics which interfere seriously with business or study, should be discouraged. 